\title{
Effect of Small-Scale Box-Fermentation on Catechin and Epicatechin Content of Lampung Cocoa Beans Varieties
}

\author{
Fahrurrozi $^{\mathrm{a}^{*}}$, Ario Betha Juanssilfero ${ }^{\mathrm{a}}$, Urip Perwitasari ${ }^{\mathrm{a}}$, Stepanie ${ }^{\mathrm{a}}$, Aryo Putra Purwanto ${ }^{\mathrm{a}}$, Imam Bagus \\ Nugroho $^{a}$, Shanti Ratnakomala ${ }^{b}$, Rizna Triana Dewic ${ }^{\mathrm{c}}$, Nur Ajijah ${ }^{\mathrm{d}}$, Puspita Lisdiyanti ${ }^{\mathrm{a}}$ \\ ${ }^{a}$ Research Center for Biotechnology, Indonesian Institute of Sciences, Bogor, West Java, 16911 Indonesia \\ ${ }^{b}$ Research Center for Biology, Indonesian Institute of Sciences, Bogor, West Java, 16911 Indonesia \\ ${ }^{c}$ Research Center for Chemistry, Indonesian Institute of Sciences, Tangerang Selatan, Banten, Indonesia \\ ${ }^{d}$ Laboratory of Plant Breeding, Indonesian Industrial, and Beverage Crops Research Institute, Indonesia \\ Corresponding author: "fahrurrozi.izzuddin@gmail.com,
}

\begin{abstract}
Cocoa is one of the food commodities that is favored by its high in polyphenols. The polyphenol and flavonoid in cocoa beans can prevent arteriosclerosis, diabetes, and their related risk factors. This research aimed to analyze the total polyphenolic contents (TPC) and flavonoid contents (TFC) of three cocoa bean varieties, namely LAM, TSH, and SUL1 collected from Lampung, Indonesia. The study also aimed to understand the effect of adding starter culture on TPC and TFC contents during cocoa beans fermentation. The TPC and TFC were extracted using ethanol from ground-dried beans and measured three times using a spectrophotometric method based on the Folin-Ciocalteu method at $760 \mathrm{~nm}$ and aluminum reagents at $510 \mathrm{~nm}$. LAM variety contained the highest TPC and TFC among other samples at $62.8 \mathrm{mg}$ GAE/g and $21.9 \mathrm{mg} \mathrm{QE} / \mathrm{g}$, respectively. The TPC and TFC decreased during both fermentation treatments with starter culture and non-starter culture. The TPC of cocoa bean with starter culture and non-starter culture decreased to $58 \%$ and $59 \%$ after fermentation. The TFC of cocoa beans with starter culture and with non-starter culture decreased after five days of fermentation, up to $58 \%$ and $75 \%$, respectively. Remarkably, the TPC and TFC in fermented cocoa beans with starter culture were higher than those with non-starter culture. Therefore, it is concluded that three days of fermentation with starter culture can produce fermented cocoa beans with the preferred flavor/quality and maintain the TPC and TFC. However, the polyphenols and flavonoids content were reduced during the fermentation process.
\end{abstract}

Keywords - Theobroma cacao L.; fermentation; starter culture; total polyphenolic content; total flavonoid content.

\section{INTRODUCTION}

Cocoa (Theobroma cacao L.) is one of the major commodities for the food, beverage, and additives industries [1]. Cocoa is processed through several lengthy steps, including fermentation. First, the fresh cocoa beans were harvested from selected cocoa pods, fermented for three to five days. Later, the fermented beans were dried and processed through several post-harvest and manufacturing steps to yield products or semi-products, e.g., paste, cocoa butter, and cocoa cake or powder.

The cocoa bean is rich in polyphenols and alkaloids consisting of about 14 to $20 \%$ of total bean weight [2]. There are three groups of polyphenols: catechins, anthocyanins, and pro-anthocyanidins. In the type of Forastero cocoa beans, fatsoluble polyphenols constitute about 15 to $20 \%$ of the bean, whereas $60 \%$ of Criollo cocoa beans polyphenols are procyanidins. The primary catechin is epicatechin, with $35 \%$ of total polyphenols. The cocoa polyphenol content varies by cocoa cultivar, area of origin, and cocoa production processes such as fermentation [3]. After the fermentation process, the number of fat-soluble polyphenols decreased to $5 \%$, and the number of epicatechins decreased by ca. $90 \%$ from its initial content [4]. During fermentation, polyphenol diffuses from cotyledons and undergoes aerobic oxidation by the activity of polyphenol oxidase. Polyphenols react with proteins converting them to an insoluble form. This process increased the brown color [5], [6].

Presently, society is well-aware of achieving better health by consuming natural products. Cocoa has been one of the promising natural products consumed as a functional food due to the high concentration of antioxidant polyphenols, which makes it leaves astringent after taste [6], [7]. Flavonoids such 
as catechins in cocoa also function as antioxidants to prevent oxidative stress damage caused by free radicals [8]. Antioxidants donate one electron for free radicals, which have one unpaired electron to reduce their activity. The ability of cocoa flavonoids to neutralize free radicals outperforms vitamin $\mathrm{C}$ and vitamin $\mathrm{E}$ by a hundredfold. Catechins are also known to have the ability to inhibit the oxidation of lowdensity lipoprotein (LDL), thus prevent the thickening of the wall of arteries, with the result of prevention of arteriosclerosis [9]. Other benefits of cocoa polyphenols are neuroprotection, cognitive modulation, cardiovascular disease, protective effect against lung cancer and colon cancer [10]. Cocoa polyphenols are also known to have the potential to protect against diabetes and its related risk factors [11].

The cocoa bean is one of the pre-eminent agricultural export products of Indonesia in addition to CPO. Indonesian cocoa sector has experienced tremendous growth, managed by a spurt of grower farmer contribution in the past 25 years. In general, there are two types of cocoa beans in Indonesia, first is kakao mulia/fine flavor cocoa, and the second is kakao lindak/bulk cocoa. Kakao mulia/fine flavor cocoa mostly from Criollo varieties and some Trinitario varieties. Several clones of fine flavor cocoa in Indonesia, namely DR 1, DR 2, and DR 38. This clone has fine flavor but less productivity and less disease resistance. Kakao lindak/bulk cocoa mostly from Forastero varieties and some Trinitario varieties. There are several clones of bulk cocoa in Indonesia, namely ICS 60, Sulawesi 1, Sulawesi 2, Sca 6, Sca 12, TSH 858. This clone has astringent flavor, higher productivity, and more resistant to disease [12], [13]. Another cocoa clone was also develop or introduce by local farmer namely MCC01 and MCC02 (Masamba Cocoa Clone) from Luwu, South Sulawesi; BCL (Bayek Clone Langkat) from Langkat, Nort Sumatra; BL 50 (Balubus 50 Kota) from Lima Puluh Kota, West Sumatra and other [13]. Most commonly cocoa variety growth in Lampung is TSH 858, Sulawesi 1, Sulawesi 2, MCC 01, MCC 02, and some local cocoa varieties.

The cocoa export accounts for Indonesia's largest foreign exchange gross from the agricultural section besides palm oil, rubber, and coconut. Nevertheless, the preponderance of Indonesia's cocoa exports mainly in the form of raw beans instead of processed cocoa, signifying that Indonesia foregoes on added value capital. Therefore, it is important to process beans domestically; for instance, applying a fermentation process could increase the brown color [5], [6].

Meanwhile, fermentation and other manufacturing processes are known to influence the phytochemical contents of cocoa products and the cocoa bean's origin [14]. Therefore, it is mainly important to examine the influence of bean's origin and post-harvest processes on the phytochemical content of cocoa beans. Therefore, the main objective of this study was to evaluate the effect of cocoa beans fermentation on the phenolic content. The information will be of significant use to the development of cocoa products for health purposes from local Indonesian cocoa cultivars.

\section{MATERIALS AND METHODS}

\section{A. Material}

Cocoa beans samples TSH 858 (TSH), Sulawesi 1 (SUL1) were obtained from Pesawaran (Lampung), and local variety
Lampung (LAM) were obtained from Pringsewu Regency, (Lampung), Indonesia. The chemicals used were ethanol, Folin-Ciocalteu reagent, sodium carbonate, gallic acid, aluminum chloride, sodium chloride, sodium nitrite, quercetin, catechin, and epicatechin. Some equipment such as rotary evaporator (Büchi, Flawil, Switzerland), centrifuge (Sigma Laborzentrifugen, Osterode am Harz, Germany), spectrophotometer, and high-performance liquid chromatography (HPLC) (Shimadzu, Kyoto, Japan), were used in this study. All chemicals were of analytical grade.

\section{B. Fermentation and sampling}

The research flowchart is shown in Fig.1. The beans were extracted from selected cocoa pods, which were then dried in a solar dryer without fermentation. To study the effect of adding starter culture and non-starter culture to the fermentation process on total polyphenolic content (TPC) and total flavonoid content (TFC), two boxes of cocoa beans mass were applying for each treatment. Each box contained $40 \mathrm{~kg}$ of mix selected fresh cocoa beans. The fermentation was conducted for five days. The cocoa beans mass was mixed using a plastic shovel every two days to give aeration to the cocoa bean mass. Sampling was taken every 24 hours, and each sample was dried using vacuum drying ALPHA 1-4 LDplus (Martin Christ, Osterode Harz, Germany) and subsequently ground to a powder with a mortar and pestle. Subsequently, cacao powder was evaluated for TPC and TFC [15].

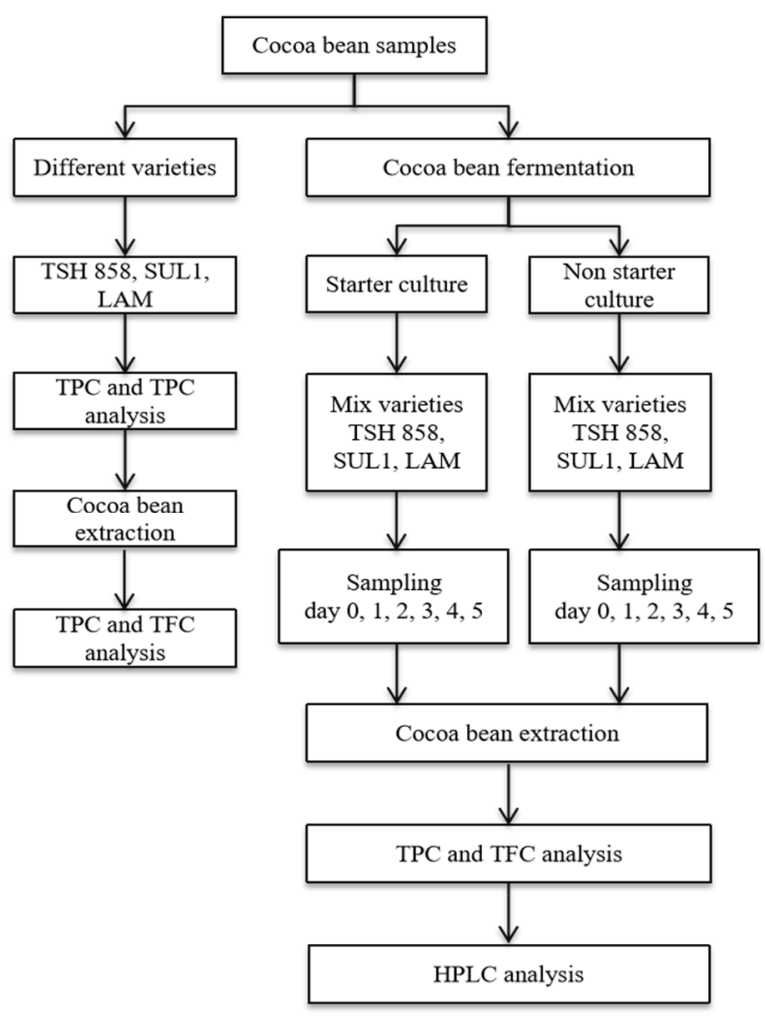

Fig. 1 Research Flowchart

\section{Total Polyphenol and Flavonoid Extraction}

All samples were weighted appropriately for $5 \mathrm{~g}$ and subsequently grounded to powder using mortars. Afterward, all samples were extracted using $15 \mathrm{~mL}$ of $80 \%(\mathrm{v} / \mathrm{v})$ ethanol (Merck, Darmstadt, Germany) three times and pooled to 45 
$\mathrm{mL}$. The solutions were homogenized and centrifuged at $10.000 \mathrm{~g}$ for 15 minutes at $4^{\circ} \mathrm{C}$. The pellet was removed, leaving the supernatant for collection in new tubes. The solutions were evaporated using BUCHI rotary evaporator (Büchi, Flawil, Switzerland) at $40^{\circ} \mathrm{C}$ and $200 \mathrm{rpm}$ to dryness. The dried sample was dissolved with $5 \mathrm{~mL}$ distilled water (DW) [16]

\section{Total Polyphenolic Content (TPC) Measurement}

According to the method described elsewhere, the total polyphenol contents (TPC) measurements were conducted using Folin-Ciocalteu reagent [17]. Briefly, five grams of the dried extracts were suspended using $5 \mathrm{~mL}$ of distilled water and diluted to a ratio 1:20 with DW in the test tubes. A 500 $\mu \mathrm{L}$ of Folin-Ciocalteu reagent (Merck, Darmstadt, Germany) was added to each tube and incubated for 3 minutes at room temperature. After that, $2 \mathrm{~mL}$ of $20 \%$ sodium carbonate solution (Merck, Darmstadt, Germany) were added to each tube to form the color complex. A blank of DW was treated similarly with the samples. The absorbance was measured at a wavelength of $760 \mathrm{~nm}$ using spectrophotometer UV-1800 (Shimadzu, Kyoto, Japan). A series concentration (0-270 $\mu \mathrm{g} / \mathrm{mL}$ ) of gallic acid (Merck, Darmstadt, Germany) was prepared to construct the standard curve. The TPC was calculated with a gradient equation from the gallic acid standard curve [16]. All of the experiments were conducted in triplicate, and the values are given as the mean of standard deviation.

\section{E. Total Flavonoid Content (TFC) Measurement}

The total flavonoid content (TFC) was measured using aluminium complexation reaction [18]. Five grams of dried extracts were suspended using $5 \mathrm{~mL}$ of distilled water (DW) and diluted to ratio 1:20 with DW in the test tubes. Appropriately, $150 \mu \mathrm{L}$ of $10 \% \mathrm{NaNO}_{2}$ reagent (Merck, Darmstadt, Germany) were added to each tube and incubated for 5 minutes at room temperature. After that, $150 \mu \mathrm{L}$ of $10 \%$ $\mathrm{AlCl}_{3}$ (Merck, Darmstadt, Germany) reagent was added to each tube and incubated for 5 minutes at room temperature. Subsequently, $1 \mathrm{M}$ of $\mathrm{NaOH}$ solution (Merck, Darmstadt, Germany) was added to each tube. A blank of DW was treated similarly. The sample absorbance was measured at $510 \mathrm{~nm}$ using spectrophotometer UV. A series concentration of quercetin (Merck, Darmstadt, Germany) was prepared to construct the standard curve. The quercetin was diluted with DW at a concentration of $1000 \mathrm{ppm}$ as much as $2 \mathrm{~mL}$. As many as $50,100,150,200,250,300$, and $350 \mu \mathrm{L}$ of that solution were added with 2750, 2700, 2650, 2550, 2500, and $2450 \mu \mathrm{L}$ of DW. The TPC was calculated with a gradient equation from the quercetin standard curve [19]. All of the experiments were conducted in triplicate, and the values are given as the mean of standard deviation.

\section{F. Measurement of Polyphenols by High-Performance Liquid Chromatography (HPLC)}

1) Cocoa beans preparations: The concentrations of phenolic and flavonoid compounds were confirmed by HPLC analysis according to the method described elsewhere [14], [20], [21]. Briefly, $2 \mathrm{~g}$ of freeze-dried cocoa beans were powdered into a particle size of ca. $1 \mu \mathrm{m}^{3}$ in a laboratory mill using $10 \mathrm{~mL}$-hexane. The sample was then rinsed twice with
$50 \mathrm{~mL}$ petroleum ether. Subsequently, the defatted powder was dried in a vacuum oven at room temperature [14], [20], [21].

2) Samples Preparations for RP-HPLC Analysis: HPLC analysis was carried out by dissolving a hundred milligram defatted cocoa powder in $3 \mathrm{~mL}$ methanol and stirred for 20 $30 \mathrm{~s}$ with an agitator. Two $\mathrm{mL}$ of methanol was adding to the rinsed agitator. The mixture was cooled for $15 \mathrm{~min}$ at $0{ }^{\circ} \mathrm{C}$ and centrifuged for $10 \mathrm{~min}$ at $2.683 \mathrm{x} \mathrm{g}$. Subsequently, the obtained supernatant was evaporated by a rotary evaporator. The residue of the evaporated sample was dissolved in $3 \mathrm{~mL}$ methanol and filtered through a $0.22 \mu \mathrm{L}$ and stored at $-20{ }^{\circ} \mathrm{C}$ until further analysis [14], [21].

Phenolic and flavonoid concentrations were analyzed using high-performance chromatography (HPLC) (LC-20AB, SPDM20A photodiode array detector (PDA), Shimazu, Kyoto Japan) equipped with an InfinityLab Poroshell 120 EC-C18 chromatography column, $150 \mathrm{~mm}$ length, $4.6 \mathrm{~mm}$ width, and particle size $2.7 \mu \mathrm{m}$ at column oven temperature $26^{\circ} \mathrm{C}$. The binary gradient method was used in HPLC analysis incorporated $2 \%$ acetic acid dissolved in water (A) and a mixture of concentrated acetic acid, water, and acetonitrile $(1: 9: 40 \mathrm{v} / \mathrm{v} / \mathrm{v})(\mathrm{B})$. The total runtime of the analysis was 93 min referring to the method described elsewhere [14, 21], as follows: a) initially $0-25 \mathrm{~min}, 10-30 \% \mathrm{~B}$; b) $25-50 \mathrm{~min}, 30-$ $40 \% \mathrm{~B}$; c) $50-75 \mathrm{~min}, 40-90 \% \mathrm{~B}$; d) $75-93 \mathrm{~min}, 10 \% \mathrm{~B}$. As many as $20 \mu \mathrm{L}$ of samples were injected onto the column, and three wavelengths 280, 360 and $520 \mathrm{~nm}$ were chosen for analysis in this investigation using HPLC-DAD. For quantitative purposes, a calibration curve was constructed by analysis of known concentrations of different standard compounds.

\section{RESULTS AND DISCUSSION}

Theobroma cacao L. consists of three main varieties, namely Criollo, Forastero, and Trinitario. The cocoa varieties have been successfully cultivated in Indonesia are Forastero and Trinitario. There are several clones of cocoa from Forastero and Trinitario varieties in Indonesia, and the clone is highly dependent on regions because cocoa is a self-crosspollinated plant [22]. The three cacao (Fig. 2) pods used in this study, namely LAM, TSH, Sulawesi 1, are known to grow well in Lampung Province, especially in Pesawaran and Pringsewu regency. All three varieties of cocoa are then mixed and used for cocoa beans fermentation experiments.

\section{A. Total polyphenolic content (TPC)}

The TPC of cocoa is affected by variety, geographical location, climate, and methods used in the fermentation and drying process. For example, in an adjacent geographical area with an identical cocoa cultivar, the cocoa bean is distinguished by the bean size, chemical composition, and organoleptic characteristics. These characteristics could lead to various flavors and aromas related to the polyphenol contents [3].

As shown in Fig. 3, every variety of cocoa beans have a different TPC concentration. The TPC concentrations for samples in descending order were observed at $62.8 ; 56.5$; and $29.3 \mathrm{mg} \mathrm{GAE} / \mathrm{g}$, for LAM, SUL1, and TSH, respectively. 

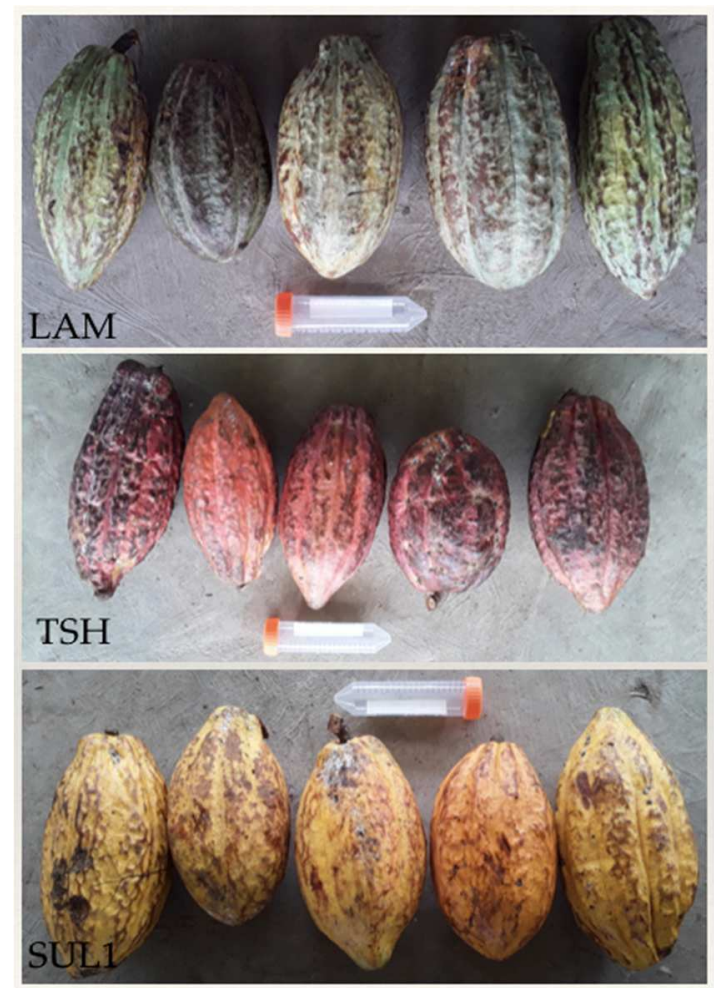

Fig. 2 The varieties of cocoa used in this study, LAM, TSH 858, SUL1.

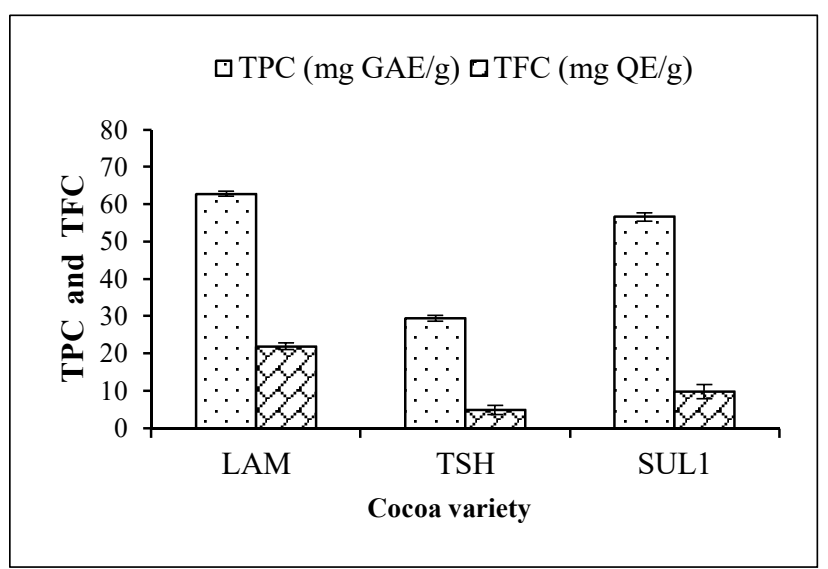

Fig. 3 Total polyphenol (TPC) and flavonoid contents (TFC) of three cocoa varieties from Lampung. LAM (local Lampung), TSH: TSH 885, SUL1: Sulawesi 1

The LAM sample has the highest TPC followed by SUL1 and TSH. SUL1 sample contained about two times higher polyphenolic content than TSH. The differences in total polyphenolic content among cocoa clones were also discovered by Oracz et al. [3]. They found differences in TPC between Indonesian, Cameroon hybrid clones, Venezuela, and Papua New Guinea Trinitario beans. The difference in TPC concentration between cocoa clones may be due to genotype varieties and growth conditions of cocoa trees [3]. Oracz et al. suggest that in addition to variety, the polyphenolic contents are also affected by the tree species, growing region, and climatic conditions [3]. It is suggested that high solar exposure induced the formation of anthocyanins and quercetin glycosides as plant selfprotection. It is also observed that the lower altitudes will result in higher polyphenol contents [4]. The growth condition of LAM is in Pringsewu Regency with the geographic condition of $104^{\circ} 48^{\prime}-105^{\circ} 08^{\prime} \mathrm{E}$ and $05^{\circ} 12^{\prime}-33^{\prime} \mathrm{S}$, whereas TSH and SUL1 are in Pesawaran regency with the geographical condition of $104,92^{\circ}-105^{\circ} 34^{\prime} \mathrm{E}$ and $5^{\prime} 12^{\circ}-$ $5,84^{\circ} \mathrm{S}$, respectively. SUL1 are identified have resistance to the disease, red pod color, bean count about 77, bean color violet; TSH resistance to disease, red pod color, bean count 70 , bean color violet; local Lampung, are much more resistant to disease, red pod color, bean count 90 , bean color violet. The violet color of the bean indicates the presence of anthocyanins in the cotyledons [23].

The fermentation process can affect the total polyphenol contents of the cocoa bean. Thus, the polyphenol contents of unfermented cocoa beans are higher than fermented cocoa beans [24]. The activity of the polyphenol oxidase, as well as permeation during bean fermentation, can cause polyphenol reduction $[24,25]$. Polyphenols react with sugar and amino acids during the fermentation process forming the brown color and reduce the astringency [6].

The TPC values of cocoa beans fermentation using a starter culture and non-starter culture during the five-day of spontaneous fermentation were depicted in Fig. 4.

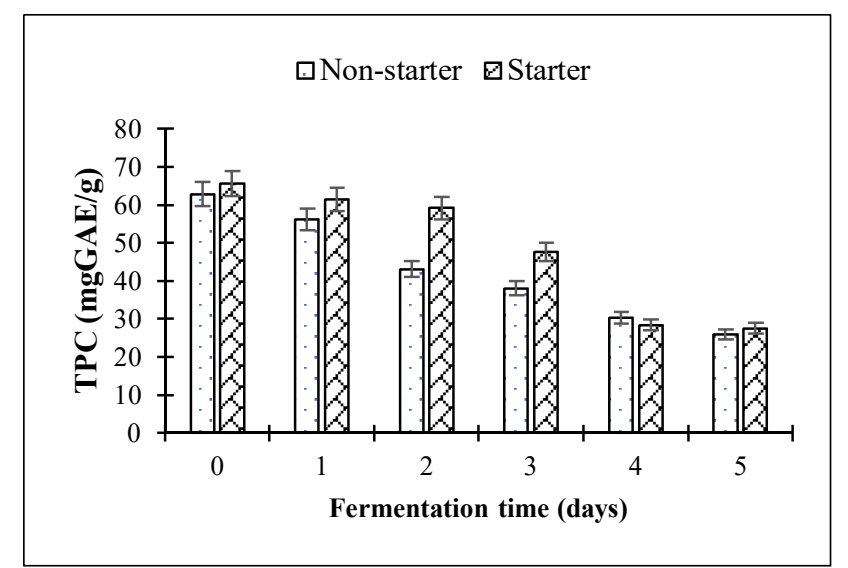

Fig. 4 Total polyphenol content (TPC) of the cocoa bean during fermentation with starter culture and non-starter culture

There was a decrease in the content of polyphenols of the cocoa bean during fermentation in both cases, fermentation with starter culture and fermentation with non-starter culture. The total polyphenol content of fermentation with non-starter culture decreased to $58.9 \%$ by the end of fermentation. During fermentation total, polyphenol content gradually decreased with a daily range of decrease from 10 to $23 \%$. On the initial to the first, second, third, and fourth day of fermentation, the TPC decreased by $10.5 \%, 31.3 \%, 39.5 \%$, and $51.7 \%$, respectively. In comparison, fermentation with starter culture TPC decreased to $58 \%$ by the end of fermentation. During fermentation total, polyphenol content was gradually decreased with a daily range of decrease from 6 to $40 \%$. On the initial to the first, second, third, and fourth day of fermentation, the TPC decreased by $6.5 \%, 9.7 \%, 27.3 \%$, and $56.7 \%$, respectively. Interestingly the content of polyphenol content at three days fermentation with starter culture was higher than fermentation with non-starter culture.

The results obtained were similar to cocoa bean fermentation from Nigeria, where the TPC decreases from the initial to the fifth day of fermentation. The TPC was $20 \%$ and reduced to $5 \%$ by the fifth day of fermentation [26]. Another 
similar pattern was also observed for Nicaraguan cocoa beans, where the TPC was significantly reduced in fermented cocoa beans than in non-fermented cocoa beans [27]. This case is under the escalation of the brown color from the beginning to the end of the fermentation process. Therefore, shorter fermentation is preferable to retain as much as polyphenolic contents of the cocoa bean.

\section{B. Total Flavonoid Content (TFC)}

Cocoa flavonoids are utilized because of their health benefits, such as antioxidative activity and preventing arteriosclerosis [8]. The TFC was measured to understand the potential benefit of cocoa flavonoids. The result was depicted in Fig. 5. LAM variety has the highest level of TFC with (21.8 $\mathrm{mg} \mathrm{QE} / \mathrm{g}$ ), followed by SUL1 and TSH (9.7 and $4.8 \mathrm{mg} \mathrm{QE} / \mathrm{g}$, respectively). This result followed the same trend since the variety of cocoa beans also affected TFC and TPC.

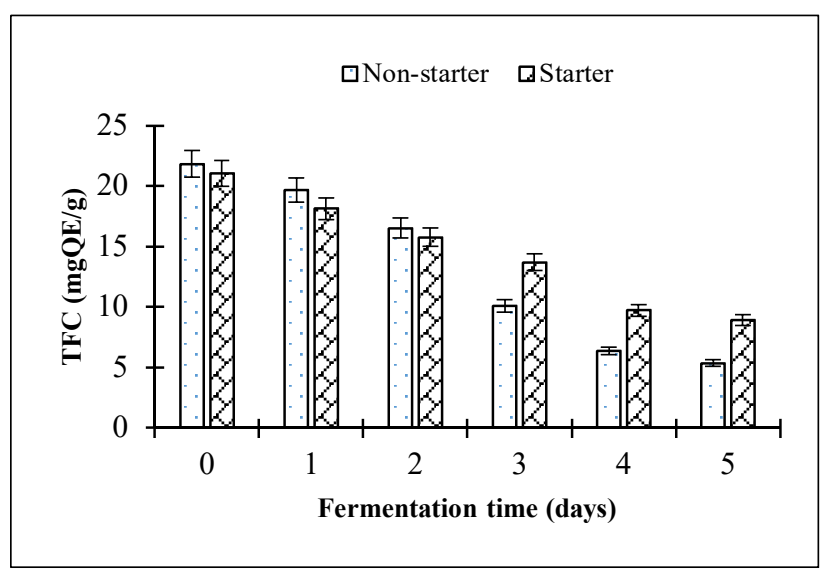

Fig. 5 Total flavonoid content (TFC) of the cocoa bean during fermentation with starter culture and non-starter culture

Flavonoids such as catechins are parts of polyphenols and might be declined during a fermentation process. Catechins are oxidized into quinones by polyphenol oxidase activity. Quinones react with amino acids, peptides, and proteins to form condensed tannins, such as brown pigments [28]. As shown in Fig. 5 there was a significant decrease in the TFC during fermentation. Fermentation with non-starter culture, the total flavonoid contents decreased to $75.2 \%$ by the end of fermentation, with a daily range of decrease from 9 to $38 \%$. The TFC on the initial day to the first, second, third and fourth day of fermentation decreased by $9.6 \%, 24.3 \%, 53.7 \%$, and $70.6 \%$, respectively. Whereas fermentation with a starter culture TFC decreased by $57.6 \%$, with a daily range of reduction from 11 to $30 \%$. The TFC on initial fermentation to the first, second, third, and fourth fermentation days decreased by $11.4 \%, 24.8 .8 \%, 34.8 \%$, and $53.4 \%$, respectively. In conjunction with TPC, the TFC at the first three days of fermentation with starter culture was higher than with non-starter culture.

\section{Polyphenol and Flavonoid Compound of Cocoa Beans}

Details of polyphenol and flavonoid compounds are affected by the fermentation process, as shown in Table 1 . The concentration of polyphenol and flavonoid decreased caused by the fermentation process, particularly on the initial of fermentation to the end of the fermentation process. More than $50 \%$ of polyphenol lost is caused by fermentation. $(+)$ - catechin loosed about $63 \%$ after five days of fermentation. Parallel with loosed of (-) - epicatechin about $68 \%$ after five days fermentation.

TABLE I

CHANGE OF POLYPHENOL AND FLAVONOID COMPOUND BEFORE AND AFTER THE FERMENTATION PROCESS.

\begin{tabular}{lcc}
\hline $\begin{array}{c}\text { Polyphenol and } \\
\text { flavonoid } \\
\text { compound }\end{array}$ & $\begin{array}{c}\text { Before fermentation } \\
\left(\mathbf{m g ~ k g}^{-1}, \mathbf{f f d m}\right)\end{array}$ & $\begin{array}{c}\text { After } \\
\text { fermentation } \mathbf{( m g} \\
\left.\mathbf{~ k g ~}^{\mathbf{- 1}}, \mathbf{f f d m}\right)^{*}\end{array}$ \\
\hline $\begin{array}{l}\text { (+) - catechin } \\
(-) \text { - epicatechin }\end{array}$ & 1450 & 529 \\
${ }^{*}$ ffdm : free fat dry matter & 25800 & 8200 \\
\hline
\end{tabular}

The epicatechin of the cocoa bean from Nigeria was found also decreased, which might arise due to oxidation, condensation, and diffusion out of cotyledon [26]. The oxidation process causes a reduction in concentration since epicatechin acts as the principal substrate of polyphenol oxidase. Other losses of catechins are due to the diffusion into fermentation sweating and polymerization of simple catechins with anthocyanidins to form complex tannins [29]. These indicate that fermentation can cause the degradation of cocoa polyphenols by physical or chemical means.

Catechin and epicatechin are commonly known to benefit health, as reported elsewhere [30-34]. The phenolic cocoa extract can protect the pancreatic beta cells against oxidative stress [30]. In vitro, an in vivo test using cocoa extract showed increased insulin secretion in BRIN-BD11 cell lines and reduced plasma glucose levels in diabetic rats [31]. Another study reported by Ryan concerning the enzymatic study of the fermented and unfermented cocoa extract against $\alpha$ glucosidase and $\alpha$-amylase; both fermented and unfermented cocoa extract showed effectively inhibited $\alpha$-glucosidase and $\alpha$-amylase [33]. Further study is needed to determine the beneficial effect of cocoa polyphenol as an antioxidant, diabetic agent, and other beneficial effects.

\section{CONCLUSION}

This study has successfully examined the influence of bean's origin (varieties) and two types of fermentation processes (with starter culture and non-starter culture) on the total polyphenol contents (TPC) and the total flavonoid contents (TFC) of cocoa beans. LAM variety has the highest TPC and TFC. Fermentation of cocoa beans with starter culture produced the highest TPC and TFC, especially after the third day of fermentation. $(+)-$ catechin and $(-)-$ epicatechin was reduced by the fermentation process. To maintain the polyphenol content, the third day of fermentation is recommended to reduce the decrease of polyphenol content during the fermentation process.

\section{ACKNOWLEDGMENT}

We are grateful to the Laboratory of Applied Microbiology, Research Center for Biotechnology, Indonesia Institute of Sciences (LIPI) for the working space and research facilities. This work was supported by the Cibinong Science Technopark Program (C-STP) (2017-2018) and Insinas Pangan Fungsional Program (2018-2019) from the Ministry of Research, Technology and Higher Education, Republic of Indonesia, and DIPA IPT 2021 Obat Tradisional. 


\section{REFERENCES}

[1] A. C. Aprotosoaie, S. V. Luca, and A. Miron, "Flavor chemistry of cocoa and cocoa products-an overview," Compr. Rev. Food Sci. Food Saf., vol. 15, no. 1, pp. 73-91, 2016.

[2] M. Á. Martín and S. Ramos, "Health beneficial effects of cocoa phenolic compounds: A mini review," Curr. Opin. Food Sci., vol. 14, pp. 20-25, 2017.

[3] J. Oracz, D. Zyzelewicz, and E. Nebesny, "The content of polyphenolic compounds in cocoa beans (Theobroma cacao L.), depending on variety, growing region, and processing operations: A review," Crit. Rev. Food Sci. Nutr., vol. 55, no. 9, pp. 1176-1192, 2015 .

[4] B. Urbanska, and J. Kowalska, "Comparison of the total polyphenol content and antioxidant activity of chocolate obtained from roasted and unroasted cocoa beans from different regions of the world," Antioxidants, Antioxidants (Basel), vol. 8, no. 8, pp. 283, 2019.

[5] V. Barišić, M. Kopjar, A. Jozinović, L. Flanjak, D. Ačkar, B. Miličević, ... and J. Babić, "The chemistry behind chocolate production," Molecules, vol. 24, no. 17, pp. 3163, 2019.

[6] J. Voigt, and R. Lieberei, "Biochemistry of Cocoa Fermentation," In Cocoa and coffee fermentations, R. F. Schwan and G. H. Fleet, Ed., Boca Raton, FL, Florida, USA: CRC Press, 2015, pp. 193-226.

[7] C. D. Di Mattia, G. Sacchetti, D. Mastrocola, and M. Serafini, "From cocoa to chocolate: The impact of processing on in vitro antioxidan activity and the effects of chocolate on antioxidant markers in vivo," Front. Immunol., vol. 8, pp. 1207, 2017.

[8] M. A. Briggs, Y. Lee, J. Fleming, C. Sponsky, and P. M. KrisEtherton, "Nutritional and physiological aspects of chocolate," In Chocolate and health chemistry, nutrition and therapy, P. K. Wilson and W. J. Hurst, Ed., Cambridge, UK: The Royal Society of Chemistry, 2015, pp. 82-102.

[9] Y. C. Cheng, J. M. Sheen, W. L. Hu, Y.C. Hung, "Polyphenols and oxidative stress in atherosclerosis-related ischemic heart disease and stroke," Oxidative medicine and cellular longevity, 2017.

[10] L. Goya, M. Á. Martín, B. Sarriá, S. Ramos, R. Mateos, and L. Bravo, "Effect of cocoa and its flavonoids on biomarkers of inflammation: studies of cell culture, animals and humans," Nutrients, vol. 8, no. 4 , pp. 212, 2016

[11] H. Cao, J. Ou, L. Chen, Y. Zhang, T. Szkudelski, D. Delmas, ... \& J. Xiao, "Dietary polyphenols and type 2 diabetes: human study and clinical trial," Crit. Rev. Food Sci. Nutr., vol. 59, no. 20, pp. 3371 3379, 2016.

[12] T. Wahyudi and Misnawi, "Sejarah, Perkembangan Penelitian dan Prospek Kakao". In "Kakao (sejarah, botani, proses produksi, pengolahan dan perdagangan)" T. Wahyudi, Pujianto, Misnawi. Ed. Yogyakarta, Indonesia: Gadjah Mada University Press, 2015.

[13] A. W. Susilo, "Botani, Keragaman Genetik, Dan Pengolahan Plasma Nutfah". In "Kakao (sejarah, botani, proses produksi, pengolahan dan perdagangan)". T. Wahyudi, Pujianto, Misnawi. Ed. Yogyakarta, Indonesia: Gadjah Mada University Press, 2015.

[14] Fahrurrozi, "Microbiological and biochemical investigations of cocoa bean fermentation," Ph.D. dissertation, Staats-und Universitätsbibliothek Hamburg Carl von Ossietzky, Germany, 2015.

[15] R. R. Utami, R. Armunanto, S. Rahardjo, and Supriyanto, "Effects of cocoa bean (Theobroma cacao L.) fermentation on phenolic content, antioxidant activity and functional group of cocoa bean shell,' Pakistan J. Nutr., pp. 948-953, 2016.

[16] C. Kaur, and H. C. Kapoor, "Antioxidant activity and total phenolic content of some asian vegetables," Int. J. Food Sci. Technol., vol. 37, pp. 153-161, 2002.

[17] S. A. Baba, and S. A. Malik, "Determination of total phenolic and flavonoid content, antimicrobial and antioxidant activity of a root extract of Arisaema jacquemontii Blume," J. Taibah Univ. Sci., vol. 9, pp. 449-454, 2015.

[18] A. Pękal, and K. Pyrzynska, "Evaluation of aluminium complexation reaction for flavonoid content assay," Food Anal. Methods, pp. 17761782,2014

[19] W. Zzaman, R. Bhat, M.Z. Abedin, and T. A. Yang, "Comparison between superheated steam and convectional roasting on changes in the phenolic compound and antioxidant activity of cocoa beans," Food Science and Technology Research, vol. 19 no. 6, pp. 949-56, 2013.

[20] N. Niemenak, C. Rohsius, S. Elwers, D. O. Ndoumou, and R. Lieberei, "Comparative study of different cocoa (Theobroma cacao L.) clones in terms of their phenolics and anthocyanins contents" Journal of Food Composition and Analysis, 19(6-7), pp. 612-619. 2006

[21] S. Elwers, A. Zambrano, C. Rohsius, and R. Lieberei, "Differences between the content of phenolic compounds in Criollo, Forastero and Trinitario cocoa seed (Theobroma cacao L.)," European Food Research and Technology, 229(6), pp. 937-948. 2009.

[22] B. Martono, "Karakteristik morfologi dan kegiatan plasma nutfah tanaman kakao. Bunga rampai inovasi teknologi bioindustri kakao," Jakarta, Indonesia: IAARD Press, 2013.

[23] W. K. Amoa-Awua, "Methods of cocoa fermentation and drying," In Cocoa and Coffe Fermentations, R. F. Schwan, and G. H. Fleet, Ed. Boca Raton, FL, Florida, USA: CRC Press, 2015, pp. 71-128.

[24] S. Sabahannur, S. Alimuddin, and Rahmawati, "Changes in phenol level and antioxidant activity of cocoa beans during fermentation and roasting," J. Food Res., vol. 7, no. 4, pp. 22-29, 2018.

[25] K. C. Racine, A. H. Lee, B. D. Wiersema, H. Huang, J. D. Lambert, A. C. Stewart, et al. development and characterization of a pilot-scale model cocoa fermentation system suitable for studying the impact of fermentation on putative bioactive compounds and bioactivity of cocoa, Foods, vol. 8, pp. 102, 2019.

[26] P. E. Aikpokpodion, and L. N. Dongo, "Effects of fermentation intensity on polyphenols and antioxidant capacity of cocoa beans.," Int. J. Sustain. Crop Prod., pp. 66-70, 2010.

[27] Y. Suazo, G. Davidov-Pardo, and I. Arozarena, Effect of fermentation and roasting on the phenolic concentration and antioxidant activity of cocoa from Nicaragua. J. Food Qual., vol. 50-56, 2014.

[28] M.S. Muñoz, J. R. Cortina, F. E. Vaillant, and S. Parra, "An overview of the physical and biochemical transformation of cocoa seeds to beans and to chocolate: Flavor formation. Critical Rev. Food Sci. Nutr., vol. 60, no.10, pp1593-1613, 2019

[29] J. F. M. Cruz, P. B. Leite, S. E. Soares, and E. Bispo, "Bioactive compounds in different cocoa (Theobroma cacao, L) cultivars during fermentation," vol. 35 no. 2, pp. 279-284, 2015.

[30] M. A. Martín, S. Ramos, I. Cordero-Herrero, L. Bravo, L., and L. Goya, (2013). Cocoa phenolic extract protects pancreatic beta cells against oxidative stress" Nutrients, 5(8), pp. 2955-2968. 2013

[31] M.R.A. Mokhtar, A. Ismail, A.G. Nawalyah, H. Muhajir, S.P.M Bohari, ... and S.M. Mansor, "Hypoglycaemic Properties of Malaysian Cocoa (Theobroma Cacao) Polyphenols-Rich Extract" International Food Research Journal. 15. 2018.

[32] D. Żyżelewicz, M. Zakłos-Szyda, J. Juśkiewicz, M. Bojczuk, J. Oracz, G. Budryn, ..., A. Jurgoński, "Cocoa bean (Theobroma cacao L.) phenolic extracts as PTP1B inhibitors, hepatic HepG2 and pancreatic $\beta$-TC3 cell cytoprotective agents and their influence on oxidative stress in rats" Food Research International, 89, pp. 946-957. 2016

[33] C.M. Ryan, "Anti-Diabetic and Anti-Obesity Activities of Cacao (Theobroma cacao) via Physiological Enzyme Inhibition" (Master's thesis). Faculty of the Virginia Polytechnic Institute and State University, United States. 2016.

[34] L. Bozzetto, G. Annuzzi, G. Pacini, G. Costabile, C. Vetrani, M. Vitale, ... A.A. Rivellese, "Polyphenol-rich diets improve glucose metabolism in people at high cardiometabolic risk: a controlled randomised intervention trial" Diabetologia, 58(7), pp. 1551-1560. 